\title{
Preliminary Rb-Sr whole-rock data for Archaean and Nagssugtoqidian rocks from the Søndre Strømfjord area, West Greenland
}

\section{F. Kalsbeek and H. P. Zeck}

The boundary between the Archaean gneiss block and the Nagssugtoqidian mobile belt (Escher et al., 1976) runs through the area south-east of the inner part of Søndre Strømfjord (fig. 42). The Archaean block here is mainly composed of brownish hypersthene gneisses cut by numerous basic dykes, the Kangâmiut dyke swarm. The Nagssugtoqidian mobile belt consists mainly of light grey biotite gneisses, formed by shearing and recrystallisation of gneisses from the Archaean block, together with numerous amphibolite layers, derived from the Kangâmiut dykes.

Biotite gneisses also occur within the Archaean block in local shear zones. In the coastal area, the basic dykes have intruded into these shear zones which have been referred to an early phase of Nagssugtoqidian deformation, Nag. 1 (Bridgwater et al., 1973), the post-dyke deformation and metamorphism being referred to as Nag. 2 . In the inland area, similar shear zones along the dykes have been interpreted as being formed after the intrusion of the dykes (Escher et al., 1976). Recent field work has shown, however, that also here the shear zones, in which the pre-existing hypersthene gneisses had been retrogressed into biotite gneisses were already in existence before the intrusion of the dykes (see Kalsbeek \& Zeck, this report).

A chemical investigation of the various gneisses shows a distinct difference in $\mathrm{Rb}$ contents between the Archaean hypersthene gneisses and the Nagssugtoqidian biotite gneisses (fig. 43 ), the biotite gneisses on average having more $\mathrm{Rb}$ than the hypersthene gneisses. Charnockitic rocks, regarded as possible parents of most of the hypersthene gneisses, and two samples of syenitic rocks in the Archaean block, have much higher $\mathrm{Rb}$ contents than the gneisses. Also samples of biotite gneiss in the pre-dyke shear zones have high $\mathrm{Rb}$ compared with the surrounding hypersthene gneisses.

To study these differences in $\mathrm{Rb}$ contents and resulting differences in $\mathrm{Rb} / \mathrm{Sr}$ ratios, and possibly to obtain information on the timing of the Nagssugtoqidian metamorphism, a number of samples of Archaean and Nagssugtoqidian rocks were selected for $\mathrm{Sr}$ isotope measurements. Apart from one series of samples of Nagssugtoqidian gneisses collected within one outcrop, the samples studied were not specially collected for isotope investigations and were taken from a large regional collection.

Analytical techniques, analytical precision etc. are as reported earlier (Kalsbeek, 1976). The isochron calculations were performed by the method of McIntyre et al. (1966). Ages were calculated using $\lambda^{87} \mathrm{Rb}=1.42 \times 10^{-11} / \mathrm{y}$, corresponding values using $\lambda^{87} \mathrm{Rb}=1.39 \times$ $10^{-11} / \mathrm{y}$ have been added in parentheses. Errors are given at the $95 \%(2 \sigma)$ confidence level.

\section{Results}

Samples of three hypersthene gneisses one of which shows charnockitic affinities in thin section and two charnockites from the Archaean complex roughly define an isochron of 


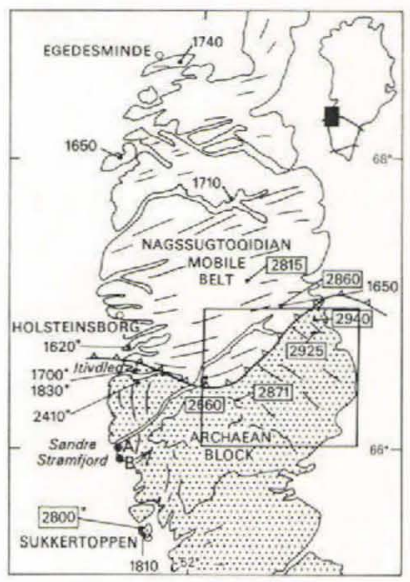

Fig. 42. Locality map of the area sampled in relationship to earlier age determinations. Boxed numbers are Archaean ages: U-Pb zircon ages (after Escher et al., 1976, fig. 71); box with asterisk: $\mathrm{Pb}-\mathrm{Pb}$ whole-rock age (Black et al., 1973). Other numbers are mainly Nagssugtoqidian ages: K-Ar biotite ages (Larsen \& Møller, 1968; with asterisk: K-Ar whole-rock isochron ages (Beckmann \& Mitchell, 1976). All ages in million years. A and B localities of two Kangâmiut dykes with age $1950 \pm 60$ m.y. (Kalsbeek et al., in prep.).

$2960(3020) \pm 60 \mathrm{~m} . \mathrm{y}$. with an initial ${ }^{87} \mathrm{Sr} /{ }^{86} \mathrm{Sr}$ ratio of $0.7018 \pm 5$ (fig. $44, \mathrm{~A}$ ). Since there is no reason to assume that these samples are cogenetic, model ages were calculated for the single samples, assuming $\left({ }^{87} \mathrm{Sr} /{ }^{86} \mathrm{Sr}\right)_{0}=0.7018$. These ages range from $2880-3060 \mathrm{~m}$.y. This agrees well with zircon U-Pb ages of 2900-3000 m.y. reported by Chessex et al. (1973) for the same suite of rocks, and is in general agreement with recent $\mathrm{Rb}-\mathrm{Sr}$ age determinations of late Archaean rocks in West Greenland (Moorbath \& Pankhurst, 1976, for the Nûk gneisses of the Godthåb district and unpublished data by R. T. Pidgeon and F. Kalsbeek for the Fiskenæsset district). One syenite sample was analysed and plots much below the 2960 m.y. isochron. Calculated with $\left({ }^{87} \mathrm{Sr} /{ }^{86} \mathrm{Sr}\right)_{0}=0.7018$ it would have an age of 2410 m.y.

Six samples of a homogeneous Nagssugtoqidian gneiss, collected within an area of $10 \times$ $10 \mathrm{~m}$, do not give a well defined isochron (fig. 44,B). A line of best fit suggests an age of $1770(1810)$ m.y. and an initial ratio of $0.7214 \pm 16$. Measurements on two Kangâmiut dykes from the coastal area gave an age of $1950(1990) \pm 60 \mathrm{~m} . y$. (Kalsbeek et al., in prep.). This was interpreted as dating the intrusion of the dykes and gives an upper age limit for the Nag. 2 phase of Nagssugtoqidian orogeny. K-Ar biotite ages (Larsen \& Møller, 1968) in the general range of 1600-1800 m.y. provide a lower limit. The 'best fit age' of $1770(1810) \pm 80$ m.y. reported here falls within these brackets but hardly refines the dating of the Nagssugtoqidian orogeny. The large scatter of the points indicates that the Sr isotopes were only partly homogenised during the Nagssugtoqidian metamorphism.
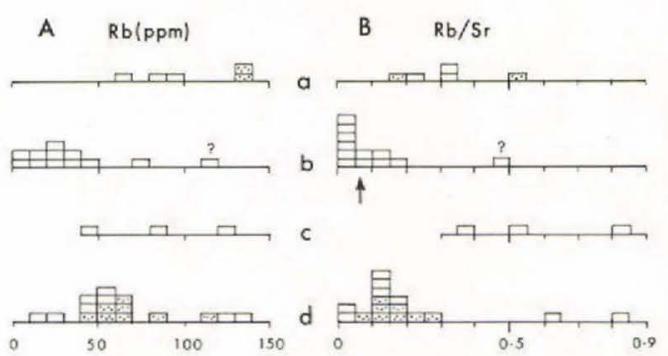

Fig. 43. Rb contents (A) and $\mathrm{Rb} / \mathrm{Sr}$ ratios (B) for 17 Archaean and 19 Nagssugtoqidian rocks. a: Archaean charnockites (white) and syenites (stippled); b: hypersthene gneisses (sample with question mark has charnockitic affinities in thin section); c: gneisses from Nag. 1 shear zones without Kangâmiut dykes; d: Nagssugtoqidian gneisses from north of the main Nagssugtoqidian boundary (Nag. 2, white) and from pre-dyke shear zones alongside Kangâmiut dykes (Nag. 1, stippled). 


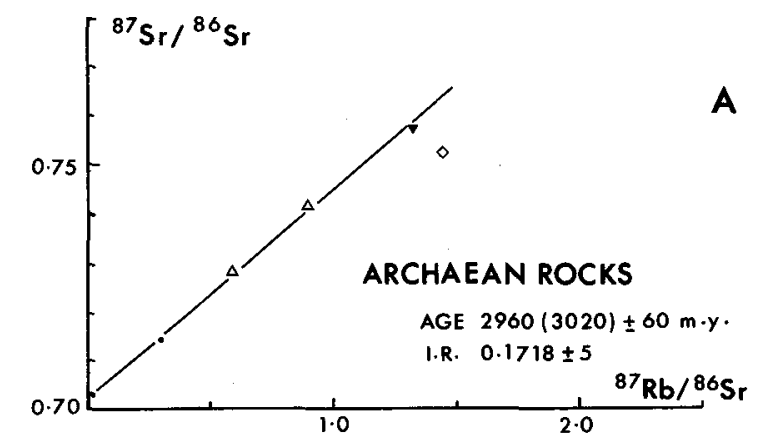

Fig. 44. Rb-Sr isochron plots for Archaean and Nagssugtogidian rocks from the Søndre Strømfjord area. I. R. = initial ${ }^{87} \mathrm{Sr} /{ }^{86} \mathrm{Sr}$

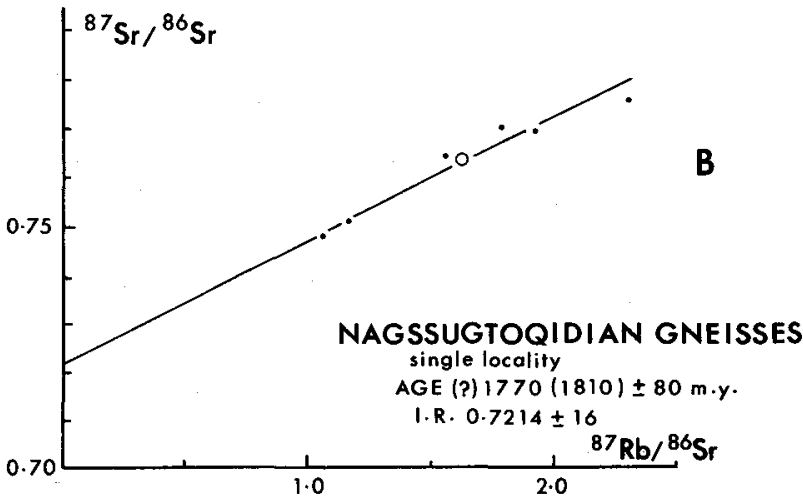
ratio. A: Archaean rocks; dots: hypersthene gneisses; open triangles: charnockites; closed triangle: hypersthene gneiss with charnockitic affinities; open square: syenite. B: Nagssugtoqidian gneisses from one single locality. C: Nagssugtoqidian gneisses, scattered samples. One sample plotting far below the best fit line was not included in the age calculation. Circle in B and C: mean value for ${ }^{87} \mathrm{Sr} /{ }^{86} \mathrm{Sr}$ and ${ }^{87} \mathrm{Rb} /{ }^{86} \mathrm{Sr}$ for the samples analysed.

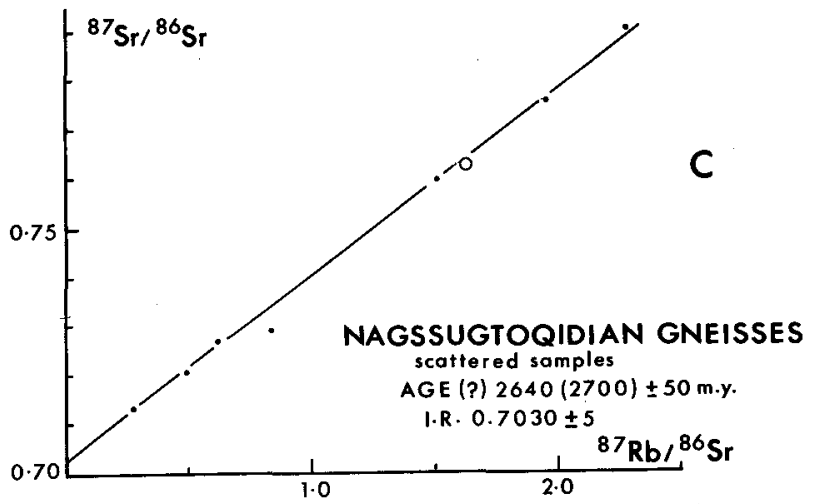

Seven samples of Nagssugtoqidian gneisses from scattered localities, including both samples from north of the Nagssugtoqidian boundary, and samples from early (Nag. 1) shear zones south of the boundary, plot roughly in the isochron diagram along a $2640(2700) \pm 50$ m.y. line with $\left({ }^{87} \mathrm{Sr} /{ }^{86} \mathrm{Sr}\right)_{0}=0.7030 \pm 5$ (fig. $44, \mathrm{C}$ ). The mean ${ }^{87} \mathrm{Sr} /{ }^{86} \mathrm{Sr}$ versus mean ${ }^{87} \mathrm{Rb} /{ }^{86} \mathrm{Sr}$ plot for the six samples of fig. $44, \mathrm{~B}$ falls near this line. 


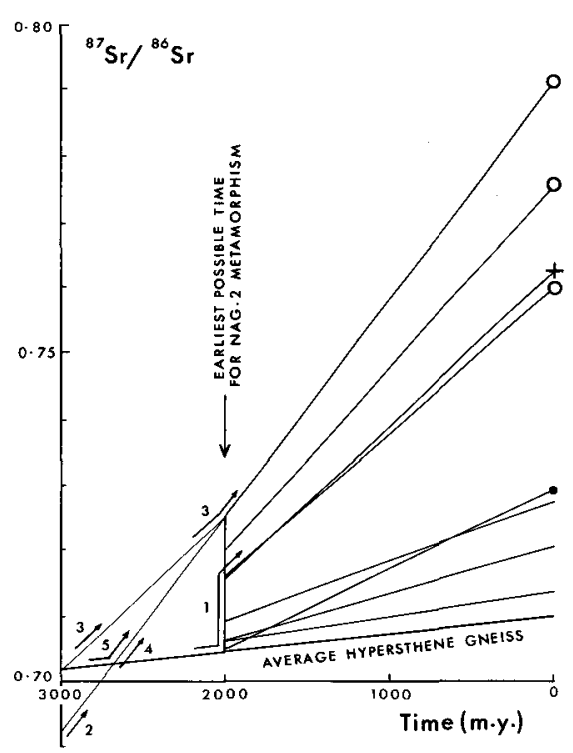

Fig. $45 .{ }^{87} \mathrm{Sr} /{ }^{86} \mathrm{Sr}$ evolution diagram for Nagssugtoqidian gneisses from the Søndre Strømfjord area. Circles: samples from Nag. 1 shear zones. Cross: mean for samples of fig. 43,B. For the explanation of heavy dot and for full interpretation, see text.

\section{Discussion}

The following discussion is based on the ${ }^{87} \mathrm{Sr}{ }^{86} \mathrm{Sr}$ evolution diagram of fig. 45. As long as a rock remains a closed system for $\mathrm{Rb}$ and $\mathrm{Sr}$ isotopes, the rate of increase in ${ }^{87} \mathrm{Sr} /{ }^{86} \mathrm{Sr}$ with time depends only on the $\mathrm{Rb} / \mathrm{Sr}$ ratio, and the ${ }^{87} \mathrm{Sr} /{ }^{86} \mathrm{Sr}$ ratio at any time in the past can be calculated from the present day values of ${ }^{87} \mathrm{Sr} /{ }^{86} \mathrm{Sr}$ and ${ }^{87} \mathrm{Rb} /{ }^{86} \mathrm{Sr}$. The upper part of the diagram shows three samples from Nag. 1 shear zones, with relatively high $\mathrm{Rb} / \mathrm{Sr}$ ratios (circles) as well as the average for the six samples of fig. $44, \mathrm{~B}$ (cross). The samples in the lower part of the diagram have lower $\mathrm{Rb} / \mathrm{Sr}$ ratios. For the sake of the argument, $2000 \mathrm{~m} . \mathrm{y}$. is taken as the age of the main, post-Kangâmiut dyke, phase of Nagssugtoqidian deformation and metamorphism, Nag. 2, this being the earliest possible date for this event (Kalsbeek et al., in prep.), and $3000 \mathrm{~m} . y$. is taken as the age of the Archaean rocks in the area (cf. fig. $44, \mathrm{~A}$ ). Several models of ${ }^{87} \mathrm{Sr} /{ }^{86} \mathrm{Sr}$ evolution in time have been indicated by numbered arrows.

(1) The Archaean hypersthene gneisses have low $\mathrm{Rb} / \mathrm{Sr}$ ratios (fig. 43) and therefore only increase slowly in ${ }^{87} \mathrm{Sr} /{ }^{86} \mathrm{Sr}$ with time (fig. 45). The diagram shows that, already $2000 \mathrm{~m}$.y. ago, several of the Nagssugtoqidian gneiss samples had considerably higher ${ }^{87} \mathrm{Sr} /{ }^{86} \mathrm{Sr}$ ratios than the average hypersthene gneiss. Therefore, unless ${ }^{87} \mathrm{Sr}$ was also added (model 1 , fig. 45), a major Rb metasomatism during Nag. 2 or later cannot explain the observed ${ }^{87} \mathrm{Sr} /{ }^{86} \mathrm{Sr}$ values. One sample with lower $\mathrm{Rb} / \mathrm{Sr}$ ratio (heavy dot in fig. 45 ) has, however, ${ }^{87} \mathrm{Sr} /{ }^{86} \mathrm{Sr}$ and ${ }^{87} \mathrm{Rb} /{ }^{86} \mathrm{Sr}$ ratios consistent with simple $\mathrm{Rb}$ enrichment during Nag. 2.

(2) A closed system evolution of ${ }^{87} \mathrm{Sr} /{ }^{86} \mathrm{Sr}$ from 3000 m.y. old parents with high $\mathrm{Rb} / \mathrm{Sr}$ ratios (model 2, fig. 45) is not possible, because in that case several of the samples would at 3000 m.y. have had ${ }^{87} \mathrm{Sr} /{ }^{86} \mathrm{Sr}$ ratios well below 0.699 , the value for primitive meteoritic matter.

(3) and (4) The Nagssugtoqidian rocks with high $\mathrm{Rb} / \mathrm{Sr}$ ratios could represent 3000 m.y. 
old rocks which, unlike the hypersthene gneisses studied (fig. 43,B), had high $\mathrm{Rb} / \mathrm{Sr}$, and which additionally were enriched in Rb at 2000 m.y. (model 3, fig. 45). Or they could derive from Rb-rich parents with an age of c. $2700 \mathrm{~m}$.y. without any change in Rb and Sr at 2000 m.y. (model 4, fig. 45). These two models are not favoured by the available field evidence. The three samples with highest $\mathrm{Rb} / \mathrm{Sr}$ ratios (circles in fig. 45) come from shear zones within Archaean hypersthene gneisses, and it seems unlikely that they represent anything else than reworked hypersthene gneisses. However, knowledge of the Archaean rocks in this region is as yet very fragmentary, both regarding age and chemistry and these models can therefore not be completely discarded.

(5) Our preferred interpretation of the data of this stage of investigation is that the Nagssugtoqidian gneisses derive from c. 3000 m.y. old parents with low Rb contents which were enriched in $\mathrm{Rb}$ to varying degrees at c. 2600-2700 m.y. (model 5, fig. 45) during the formation of the Nag. 1 shear zones. The basis of this hypothesis is that the three samples from Nag. 1 shear zones have ${ }^{87} \mathrm{Sr} /{ }^{86} \mathrm{Sr}$ evolution lines that intersect the hypersthene gneiss line at that time. Other models for ${ }^{87} \mathrm{Sr} /{ }^{86} \mathrm{Sr}$ evolution than the ones outlined above can be conceived but appear less likely at this stage.

The interpretation of the age of 2640 m.y. suggested by the isochron plot of fig. 44,C depends on the model for ${ }^{87} \mathrm{Sr} /{ }^{86} \mathrm{Sr}$ evolution chosen. In the case of model 1 (addition of $\mathrm{Rb}$ and ${ }^{87} \mathrm{Sr}$ to $\mathrm{Rb}$-poor parents during Nag. 2 or slightly earlier) and 3 (addition of $\mathrm{Rb}$ to Rb-rich 3000 m.y. old parents) it is difficult to imagine how anything like an isochron could develop.

In the case of model 4 , the 2640 m.y. age would correspond to the formation of the gneisses which by later (isochemical) deformation and metamorphism gave rise to the Nag. 1 and Nag. 2 rocks.

In the case of model 5, the $2640 \pm 50$ m.y. age would date the Rb enrichment during the formation of the Nag. 1 shear zones. Provisionally we prefer this last possibility. This model implies that Nag. 2 rocks with high $\mathrm{Rb} / \mathrm{Sr}$ ratios (e.g. the samples of fig. 44,B) had also undergone $\mathrm{Rb}$ metasomatism at this early stage.

\section{Tentative conclusions}

(1) Rocks from the Archaean basement in the Søndre Strømfjord region have ages in the order of 2900-3000 m.y.

(2) Formation of shear zones (Nag. 1) and associated Rb-metasomatism took place approximately $2600-2700 \mathrm{~m}$.y. ago.

(3) The age of the main Nagssugtoqidian metamorphism (Nag. 2) is in the order of 1800 m.y.

(4) At least part of the gneisses affected by Nag. 2 metamorphism underwent metasomatic Rb enrichment already during Nag. 1.

Suitable material for further geochemical investigation of the various gneiss types was collected in the summer of 1977 and will be used to test and refine these preliminary conclusions. If a late Archaean age of the shear zones is substantiated by later investigations, it will have to be considered whether or not the use of the term ' $\mathrm{Nag}$. 1', both for the deformation that initiated the shear zones and for the much later deformation that took place contemporaneously with the intrusion of the Kangâmiut dykes, should be continued. 


\section{Acknowledgement}

The samples of Nagssugtoqidian gneiss from the single locality (fig. 44,B) have been collected by K. Secher (GGU).

\section{References}

Beckmann, G. E. J. \& Mitchell, J. G. 1976: Palaeomagnetic and geochronological work in central West Greenland. Earth Planet. Sci. Lett. 30, 269-280.

Black, L. P., Moorbath, S., Pankhurst, R. J. \& Windley, B. F. 1973: ${ }^{207} \mathrm{~Pb} /{ }^{206} \mathrm{~Pb}$ whole rock age of the Archaean granulite facies metamorphic event in West Greenland. Nature, Phys. Sci. 244, 50-53.

Bridgwater, D., Escher, A., Nash, D. F. \& Watterson, J. 1973: Investigations on the Nagssugtoqidian boundary between Holsteinsborg and Kangâmiut, central West Greenland. Rapp. Grønlands geol. Unders. 55, 22-25.

Chessex, R., Delaloye, M., Gülacar, F. \& Escher, A. 1973: U-Pb isotopic ages of zircons from Precambrian rocks of West Greenland. Fortschr. Miner. 50, 60-61.

Escher, A., Sørensen, K. \& Zeck, H. P. 1976: Nagssugtoqidian mobile belt in West Greenland. In Escher, A. \& Watt, W. S. (edit.) Geology of Greenland, 76-95. Copenhagen: Geol. Surv. Greenland.

Kalsbeek, F. 1976: Rb-Sr whole-rock age of the Ilivertalik Granite and other rocks from the Fiskenæsset area. Bull. geol. Soc. Denmark 25, 85-88.

Kalsbeek, F., Bridgwater, D. \& Zeck, H. P. in prep.: A $1950 \pm 60$ Ma Rb-Sr whole-rock isochron age from two Kangâmiut dykes and the timing of the Nagssugtoqidian (Hudsonian) orogeny in West Greenland.

Larsen, O. \& Møller, J. 1968: Potassium-argon age studies in West Greenland. Can. J. Earth Sci. 5, 683-691.

McIntyre, G. A., Brooks, C., Compston, W. \& Turek, A. 1966: The statistical assessment of Rb-Sr isochrons. J. geophys. Res. 71, 5459-5468.

Moorbath, S. \& Pankhurst, R. J. 1976: Further rubidium-strontium age and isotope evidence for the nature of the late Archaean plutonic event in West Greenland. Nature, Lond. 262, 124-126.

H.P.Z., Institut for Petrologi, University of Copenhagen, Oster Voldgade 10, 1350 Copenhagen $K$. 